\title{
Pembinaan Keagamaan Model Gaudya Vaisnava di Pasraman Sri-Sri Nitai Gaurangga Desa Werdhi Bhuana Kecamatan Mengwi Kabupaten Badung
}

Ida Bagus Putu Supriadi ${ }^{1}$

Fakultas Dharma Duta

Institut Hindu Dharma Negeri Denpasar

Abstract

The religious formation of the Gaudya Vaisnava model viewed from the persuasion communication strategy is very interesting to study, because the activity will describe the elements of communication whether it is effective or not. From the point of view of the communicator, for example, is it capable of applying effective message delivery techniques? in terms of communicant, does it have the characteristics to be able to understand the meaning of the message as intended by the communicator? From the message element, is the message important to be known by the communicant ?. From the media element, is the media used to convey the message effective enough? And from the element of effect, whether the similarity in meaning of messages sent and received is able to change the communicant's attitude or behavior. Thus the process of religious formation will achieve its objectives if the elements of communication work effectively.

There is no research on this matter, so it is not yet known whether the religious formation of the Gaudya Waisnava model has been effective or not. For this reason, this research was specifically carried out to describe and interpret (1) how does the religious development activities of the Gaudya Vaisnava model in Pasraman Sri-Sri Nitai Gaurangga? (2) how is the function of religious formation of the Gaudya Vaisnava model in Pasraman Sri-Sri Nitai Gaurangga? And (3) what is the meaning of the religious formation of the Gaudya Vaisnava model in Pasraman Sri-Sri Nitai Gaurangga?

The results of the study (1) the activities of religious formation of the Gaudya Vaisnava model include: (a) the activities of receiving students / new students; (b) the implementation of unlawful education; (c) Brahmin Diksa implementation; (d) carrying out the task of spreading the teachings of Gaudya Vaisnawa (2) the function of religious formation of the Gaudya Vaisnava model includes social functions and religious functions. Social

${ }^{1}$ Ib_supriadi@ihdn.ac.id 
functions encourage members to carry out their social life tasks better. Whereas the religious function encourages its members to be able to harmonize all aspects of their lives. (3) The meaning of religious formation in the Gaudya Vaisna model includes social and religious meanings. Social meaning is intended to increase the insight of its members to be more inclusive among humans. The religious meaning is intended to increase the insight of its members in order to be able to harmonize all their life activities.

Keywords Religious fonding, The Gaudya Vaisnava model, Pasraman

\section{PENDAHULUAN}

Pembinaan keagamaan dalam organisasi agama-agama di Indonesia mengalami perkembangan yang menarik. Salah satu yang sedang berkembang adalah pembinaan keagamaan model Gaudya Vaisnava, yang dikembangkan oleh perkumpulan Kesadaran Krishna di Indonesia, yang juga berkembang sangat pesat di Bali. Di Bali sendiri, yang terkenal dengan sistem kekerabatan yang kuat, dan sistem adat yang kokoh, menimbulkan pertanyaan, seberapa banyak umat Hindu tradisional Bali yang mengikuti model pembinaan keagamaan Hindu di luar adat istiadatnya?.

Jawabannya, sudah cukup banyak, bahkan melebihi angka 5000-an orang. Ada apa dan bagaimana bisa terjadi ?. Apakah model pembinaannya demikian hebat, sehingga ribuan umat Hindu Bali terkonversi?. Pertanyaan inilah yang menarik untuk ditemukan jawabannya secara ilmiah. Penelusuran lebih cermat telah dilakukan. Salah satu tempat pembinaan keagamaan model Gaudya Vaisnava adalah Pasraman Sri-Sri Nitai Gaurangga, yang berlokasi di Banjar Sayan Baleran Desa Werdi Bhuana Kecamatan Mengwi Kabjupaten Badung. Untuk memberikan jawaban yang holistik dan terfokus, maka ada tiga masalah yang dirumuskan : (1) bagaimana kegiatan pembinaan keagamaan model Gaudya Vaisnava di Pasraman Sri Sri Nitai Gaurangga? (2) Bagaimana fungsi pembinaan keagamaan model Gaudya Vaisnava di Pasraman Sri Sri Nitai Gaurangga? (3) Bagaimana makna pembinaan keagamaan model Gaudya Vaisnava di Pasraman Sri Sri Nitai Gaurangga?

Berdasarkan ketiga rumusan masalah inilah penelitian ini dilakukan dengan judul: "Pembinaan Keagamaan Model Gaudya Vaisnava di Pasraman Sri-Sri Nitai Gaurangga Desa Werdhi Bhuana Mengwi Badung"

\section{Metode Penelitian}

Lokasi penelitian terletak di Pasraman Sri Sri Nitai Gaurangga Desa Werdi Bhuana, Mengwi, Badung. Alasan dipilihnya Pasraman Sri Sri Nitai Gaurangga sebagai lokasi penelitian karena: (1) secara teoritis dalam pasraman ini telah dilaksanakan pembinaan keagamaan model Gaudya Vaisnava secara periodik, yang realitas sosialnya dapat dideskripsikan dan diinterpretasikan berdasarkan prinsipprinsip keilmuan, yaitu sistematis, logic, dan rasional. (2) secara praktis lokasi penelitian ini mudah dijangkau sehingga 
diperkirakan tidak banyak mengeluarkan biaya, waktu dan tenaga.

Dalam penelitian ini digunakan jenis dan sumber data primer dan sekunder. Sedangkan yang dimaksud dengan informan adalah orang yang memberikan informasi. Dalam penelitian kualitatif, cara untuk menentukan informan dilakukan berdasarkan pertimbangan tertentu, misalnya karena orang itu memiliki kompetensi di bidangnya maupun karena orang itu mengalami sendiri peristiwa yang ingin dideskripsikan melalui penelitian ini sehingga dipandang layak sebagai informan. Teknik atau cara menentukan informan seperti digambarkan di atas dikenal sebagai purposive sampling (Sugiyono, 2010). Teknik itulah yang diterapkan dalam penelitian ini sebagai teknik penentuan informan. Dalam hal ini adalah orang-orang yang memiliki pengetahuan dan pengalaman mengikuti kegiatan pembinaan keagamaan itu.

Teknik pengumpulan data yang digunakan adalah observasi (pengamatan), wawancara (interview), studi dokumen dan triangulasi. Dalam penelitian ini, digunakan teknik observasi terfokus karena peneliti memfokuskan diri pada ketiga rumusan masalah yang telah ditentukan. Dengan observasi model ini peneliti berharap memperoleh data yang dibutuhkan, dan terperinci, tidak hanya pada gejala yang tampak saja, melainkan sapai pada makna yang terkandung dibalik gejala yang tampak itu.

$\begin{array}{ccc}\text { Teknik wawancara yang } \\ \text { dilakukan } & \text { bertujuan untuk }\end{array}$
mengumpulkan data dan fakta yang relevan dengan tujuan penelitian. Dalam hal ini, digunakan teknik wawancara semi terstruktur (Semistructure interview). Jenis wawancara ini termasuk dalam katagori in-depth atau wawancara mendalam. Dalam pelaksanaannya lebih bebas bila dibandingkan dengan wawancara terstruktur. Tujuan dari wawancara jenis ini adalah untuk menemukan permasalahan secara lebih terbuka, dimana pihak yang diajak wawancara diminta pendapat dan ide-idenya, karena itu dalam wawancara diperlukan mendengar secara teliti dan mencatat apa yang dikemukakan oleh informan.

Teknik studi dokumen dalam penelitian ini berguna untuk mengumpulkan data yang bersifat fenomenal yang penting untuk dokumentasi, seperti peristiwa bersejarah, peristiwa menarik yang monumental mengenai kegiatan upacara diksa di Pasraman Sri Sri Nitai Gaurangga. Dalam penelitian ini, teknik pengumpulan secara triangulasi berarti menggabungkan ketiga teknik terdahulu yaitu observasi partisipan, wawancara mendalam dan studi dokumen. Teknik ini peneliti gunakan untuk menguji kredibilitas data, yaitu mengecek kredibilitas data dengan berbagai teknik pengumpulan data dan berbagai sumber data.

Untuk memperoleh tulisan yang sahih dan dapat dipertanggungjawabkan maka data yang diperoleh melalui teknik pengumpulan data tidak langsung dapat dipergunakan dalam penulisan suatu tulisan ilmiah. Data tersebut harus diolah dahulu dengan teknik pengolahan data. Dalam penelitian kualitatif analisis data dilakukan sejak sebelum memasuki lapangan, selama di lapangan, dan setelah selesai di lapangan. Nasution (1988) sebagai mana dikutip Sugiyono (2010:336) menyatakan,: "Analisis telah mulai sejak merumuskan dan menjelaskan masalah, sebelum terjun ke 
lapangan, dan berlangsung terus sampai penulisan hasil penelitian. Analisis data menjadi pegangan bagi penelitian selanjutnya sampai ditemukan hipotesis atau kesimpulan, bahkan jika mungkin teori yang grounded".

Setelah analisis kemudian dilakukan penyajian data. Ini merupakan kegiatan penyajian informasi, melalui tehnik pemilihan kata yang tepat dalam susunan kalimat yang sesuai dengan bahasa ragam ilmiah. Beberapa kalimat yang saling bertautan akan membentuk sebuah paragraf yang berisi informasi yang runut. Mulai dari pernyataanpernyataan informan yang disampaikan secara emic, kemudian dianalisis dan dinterpretasikan guna diperoleh suatu pernyataan berupa pendapat peneliti sendiri yang disampaikan secara etic. Pendapat peneliti inilah yang disebut tesis.

\section{PEMBAHASAN}

\section{Kegiatan Keagamaan Model Gaudya Vaisnawa}

Kegiatan keagamaan model Gaudya Vaisnawa yang dideskripsikan, meliputi (1) kegiatan penerimaan sisya/murid baru; (2) pelaksanan diksa harinam; (3) pelaksanaan diksa brahmana; (4) pelaksanaan tugas penyebarluasan ajaran Gaudya Vaisnawa.

\section{Kegiatan Penerimaan Sisya Baru/Pemula}

Pasraman Sri-Sri Nitai Gaurangga, menerima siapa saja yang sungguhsungguh menaruh minat untuk mempelajari dan mempraktikkan ajaran Kesadaran Krishna sesuai program pembinaan yang dilaksanakan oleh Pasraman Sri Sri Gaura Nitai. Sisya baru tersebut kemudian memantapkan diri untuk aktif belajar dan memohon kepada pimpinan pasraman untuk dibina dan didaftar sebagai peserta pemula. Setelah satu tahun atau lebih telah mengikuti kegiatan kebhaktian keluarga dan kebhaktian kolektif di pasraman, apabila pimpinan pasraman menganggap peserta pemula ini telah memahami dan melaksanakan etika vaisnawa; tekun melakukan japa, kirtanam, membaca/menyanyikan Bhagavadgita dan Srimadbhagavatam, maka dapat direkomendasikan untuk mengikuti tes tertulis dan tes perilaku sebagai salah satu syarat mengikuti diksa harinam.

Menurut pengakuan para informan bahwa mereka tertarik untuk mengetahui praktik keagamaan model Gaudya Vaisnawa, dengan berbagai alasan. Pertama mereka tertarik pada ajaran Bhagavadgita versi Perkumpulan Kesadaran Krishna karena selama menjadi penganut Hindu tradisional Bali, belum pernah belajar Bhagavatgita sebagaimana ulasan acharya dan pendiri Perkumpulan Kedasaran Krishna. Kedua mereka mendapat tuntunan dan bimbingan yang teratur dan terarah tentang ajaran kerohanian, yang tidak pernah mereka dapatkan ketika masih sebagai penganut Hindu tradisional Bali. Ketiga, dalam Perkumpulan Kesadaran Krishna dikembangkan pergaulan sosial yang setara sesama penyembah sesuai aturan dan peraturan sisya Perkumpulan Kesadaran Krishna, sehingga tidak ada bahasa sor-singgih sesama peserta. Berbeda dengan kehidupan tradisi Bali yang masih cendrung memelihara ikatan feodalisme yang kuat. Keempat masyarakat tradisional Bali terlalu mudah mengasingkan warganya jika terbukti tidak mentaati aturan. 


\section{Pelaksanaan Diksa Harinam}

Para pemula yang sudah mengikuti proses pembinaan dan memperoleh rekomendasi pembinanya diberikan kesempatan untuk mengikuti diksa-harinam. Upacara diksa-harinam adalah upacara penerimaan sebagai sisya oleh seorang guru kerohanian. Setelah melaksanakan diksa-harinam seorang sisya wajib mengikuti segala perintah gurunya dalam rangka menyiapkan dirinya memasuki kehidupan yang berkesadaran Krishna secara utuh.

Menurut pengakuan para informan bahwa mereka tertarik untuk mengikuti diksa harinam model Gaudya Vaisnawa, dengan berbagai alasan. Pertama mereka meyakini bahwa diksa harinam merupakan proses awal untuk diterima menjadi murid seorang guru kerohanian. Tanpa mengikuti diksa harinam ini pengetahuan rohani tidak mungkin mereka peroleh, karena diksa harinam merupakan pintu masuk untuk mendapatkan ilmu kesadaran Krishna yang didambakannya. Kedua mereka meyakini bahwa diksa harinam merupakan garis penghubung secara rohani antara dirinya dengan guru kerohaniannya. Dalam hal ini kepatuhan dan ketaatannya melaksanakan ajaran sang guru akan dievaluasi secara terus menerus sehingga ia terpacu untuk memperbaiki segala kesalahan dan selalu berpegang teguh pada kebenaran etika waisnawa yang dijadikan berpikir, berkata, dan bertindak dalam kehidupan sehari-hari. Ketiga, dalam Perkumpulan Kesadaran Krishna dikembangkan pergaulan suci (sadhusanga) yaitu semacam sistem persaudaraan secara rohani antara sesama penyembah yang saling mengingatkan berbagai kemungkinan yang menyebabkan seseorang keluar dari rel kebenaran atau prinsip-pripsip kesadaran Krishna dan menghormati penyembah yang lebih senior untuk memperoleh bimbingan dan suri tauladan darinya.

\section{Pelaksanaan Diksa Brahmana}

Setelah beberapa tahun lamanya berada dibawah bimbingan Sang Guru Kerohanian, jika dipandang memenuhi syarat menjadi seorang adhikari, gurunya akan merekomendasikan untuk mengikuti diksa-brahmana yaitu upacara penyucian diri untuk persiapan mengemban tugas-tugas rohani menyebarluaskan ajaran Gaudya Vaisnawa kepada dunia.

Menurut pengakuan para informan bahwa mereka yang saat ini sedang melaksanakan tugas dan kewajiban suci sebagai sisya kerohanian pada taraf diksa harinam, selalu berharap dapat melakukannya sesempurna mungkin, sampai mereka memperoleh rekomendasi guru kerohaniannya untuk mengikuti diksa brahmana. Ketertarikannya untuk mengikuti diksa brahmana model Gaudya Vaisnawa, dengan alasan yang intinya hampir sama, yaitu: (1). Mereka meyakini bahwa diksa brahma merupakan proses lanjutan yang dipersiapkan untuk mampu mengemban tugas-tugas kerohanian yang diberikan guru kerohaniaannya. (2) Mereka meyakini bahwa diksa brahmana adalah salah satu kualifikasi awal sebagai penyembah Tuhan Sri Krishna, sehingga memungkinkan mereka memiliki hubungan pribadi yang khusus dengan kepribadian Tuhan yang Mahaesa Sri Krishna melalui perantara guru kerohaniannya. garis penghubung secara rohani antara dirinya dengan guru kerohaniannya. (3) Dalam status diksa 
brahmana mereka memperoleh kesempatan untuk melayani arca kepribadian Tuhan Yang maha Esa Sri Krishna, sebagai seorang pujari sehingga memungkinkan memperoleh karunia yang tanpa sebab, jika seluruh pengabdian sucinya bersifat murni tanpa dinodai sifat-sifat pementingan diri.

\section{Pelaksanaan Tugas Penyebarluasan Ajaran Gaudya Vaisnava}

Sisya kerohanian yang sudah melakukan diksa brahmana, telah menyiapkan diri melaksanakan perintah guru, di samping sebagai tenaga inti organisasi secara internal, juga yang terpenting adalah menyebarluaskan ajaran Sang guru ke dunia luar, sesuai dengan sinergitas organisasi pasraman dan organisasi induk.

Menurut pengakuan para informan bahwa mereka yang saat ini sudah cukup lama melaksanakan tugas dan kewajiban suci sebagai sisya kerohanian pada taraf diksa harinam, dan telah banyak mendapatkan pengalaman dalam pergaulan suci (sadhusanga) berharap mendapatkan kesempatan untuk ditugaskan oleh guru kerohaniannya untuk menyebarluaskan ilmu kesadaran Krishna ke dunia luar. Artinya memimpin aktivitas sankirtana dan penyebarluasan ajaran kesadaran Krishna di luar asramnya. Para penyembah yang sudah menjalani tugas dan kewajiban kesadaran Krishna dalam katagori senior, hampir seluruhnya telah diberikan tugas untuk menyebarluaskan ajaran guru kerohaniannya ke seluruh pelosok daerah dan mereka sangat bangga dan selalu bersemangat mengajarkan ilmu kesadaran Krishna dengan tujuan untuk mengajak orangorang lain lebih banyak untuk menjadi penyembah kepribadian Tuhan Yang maha esa Sri Krishna dan mendapatkan karunia Beliau, sehingga lebih banyak manusia yang hidup berbahagia secara rohani dibawah bimbingan guru-guru kerohanian Sampradaya Kesadaran Krishna.

\section{Fungsi Pembinaan Keagamaan Model Gaudya Vaisnava}

1) Fungsi Sosial

Fungsi sosial yang dimaksud disini adalah pasraman mengemban tugas memudahkan kelancaran individu anggota dan partisipannya untuk melaksanakan tugas-tugas kehidupan dirinya sendiri, keluarganya, kelompok sosialnya, dan masyarakat lingkungan sekitarnya. Misalnya setiap anggota dan partisipannya didorong untuk hidup berkesadaran krishna yang memperhatikan kesejahteraan dirinya, keluarganya, orang-orang lain di sekitarnya, kelompok sosialnya, dan organisasi perkumpulan kerohanian Gaudya Vaisnava.

Menurut pengakuan para informan, bahwa pelaksanaan fungsi sosial ini belum terlaksana sepenuhnya. Perkumpulan Kesadaran Krishna, dalam konsulidasi ke dalam kelompoknya pada umumnya telah terlaksana dengan baik, namun sayang masih terbatas di lingkungan kelompoknya. Ada semacam keraguan bergaul dengan orang-orang di luar kelompoknya, karena ada kekhawatiran pergaulannya akan terkontaminasi oleh pikiran mayavadi. Disini tampak secara tidak disadari terbangun sekat yang kuat antara masyarakat luar dan masyarakat internal mereka. Wajarlah kalau pihak luar menilai Perkumpulan Kesadaran Krishna bersifat ekslusif. Dari penampilannya ketika melakukan komunikasi persuasi dengan masyarakat luar, hampir semua 
tokoh-tokohnya menyampaikan dengan argumentasi penguasaan kitab Bhagavad-gita dan Srimadbhagavatam dengan sangat fasih dan cendrung membuat kesimpulan kebenaran sephiak sehingga memposisikan pendengarnya yang belum masuk perkumpulan Kesadaran Krishna dalam posisi sedang membelakangi kebenaran yang telah mereka praktikan selama ini. Hal ini memberi kesan seolah-olah mereka merasa benar menurut persepektifnya sendiri. Mungkin saja hal ini yang menyebabkan tokoh-tokoh Hindu atau tokoh agama yang lainnya merasa curiga bahwa cara rekruitment pengikut baru semacam ini dapat dipersoalkan karena dapat saja dituduhkan sebagai tindakan mengagamakan orang-orang yang sudah menganut suatu agama agama tertentu.

2) Fungsi Religius

Dilihat dari kacamata spiritual, Perkumpulan Kesadaran Krishna dan pasraman-pasraman yang diayominya, berusaha sepenuhnya mewujudkan fungsi kerohanian sesuai dengan perintah mahagurunya Srila Prabhupada. Kesadaran Krishna sepenuhnya dimaksudkan sebagai kesadaran rohani. Semua kegiatan phisik hendaknya dilandasi dengan Kesadaran Krishna, karena itu doa, mantra, ritual menjadi landasan setiap aktivitas kehidupan. Ini yang menurut kelompok ini sebagai pembinaan keagamaan berbasis god centre, berpusat pada Tuhan, Sri Krishna. Menurut pengakuan para informan bahwa fungsi untuk merohanikan kehidupan para pengikutnya sudah dilaksanakan melalui kegiatan-kegiatan kerohanian yang telah dilaksanakan dengan baik di senter-senter kegiatan seperti pasraman-pasraman yang didirikan dan dikelola dengan sebaik- baiknya dan secara periodik dikunjungi oleh Mahaguru kerohanian Kesadaran Krishna Internasinal dari luar negeri.

\section{Makna Pembinaan Keagamaan Model Gaudya Vaisnava}

Prinsip-prinsip yang bersifat mengatur kehidupan para vaisnava bertujuan melatih dan mendidik perilaku bahkan merubah perilaku yang bersifat keduniawian menjadi perilaku rohani menurut standar vaisnava. Dalam hubungan ini, makna pembinaan keagamaannya, meliputi : (1) makna yang bersifat sosial. (2) makna yang bersifat religius.

Makna yang bersifat sosial, bahwa aktivitas pasraman dan anggotaanggota meningkatkan kualitas interaksi dan komunikasi sosial antara anggota yang satu dengan anggota yang lain. Hal ini penting untuk bersama-sama menegakkan dan memperjuangkan harkat dan martabat kemanusiaannya. Ajaran Hare Krishna hampir seluruhnya mengajarkan untuk menjalin hubungan interaksi dan komunikasi dengan sesama manusia dan makhluk hidup yang lain, untuk saling memberikan kontribusi bagi kehidupan sosialnya masing-masing. Namun pada kenyataannya, karena mereka membatasi hubungan sosial dengan orang lain yang berada di luar kelompoknya, maka fungsi sosial yang telah dilaksanakan secara efektif baru pada tataran intern kelompoknya saja, belum secara kemanusiaan yang universal.

Makna yang bersifat religius, bahwa telah menjadi semacam indoktrinasi, bahwa setiap orang yang telah melakukan diksa harinam, apalagi diksa brahmana telah diterima sebagai murid guru kerohanian secara sah dan diantarkan pada kehidupan 
berkerohanian sepenuhnya. Sejak saat itu, seluruh kehidupannya berada dalam pergaulan rohani dengan sesama murid perkumpulan kesadaran krishna di dunia, dan diyakini sebagai proses perohanian hidupnya melalui aktivitas japa, kirtana, dan ritual. Apabila semua aktivitas kerohanian itu dilakukan dengan tunduk hati, sesuai prinsipprinsip etika vaisnava, maka seluruh kehidupannya dipandang dan diyakini bersifat rohani. Itulah doktrin terpenting dalam perkumpulan Kesadaran Krishna yang diajarkan pada pasramanpasraman yang diayominya, termasuk Pasraman Sri Sri Nitai Gaurangga.

\section{KESIMPULAN DAN SARAN}

Kegiatan pembinaan keagamaan model Gaudya Vaisnava melipiuti: (1) kegiatan meneriman sisya baru/pemula; (2) pelaksanan diksa harinam; (3) pelaksanaan diksa brahmana; (4) pelaksanaan tugas penyebarluasan ajaran Gaudya Vaisnawa.

Fungsi pembinaan keagamaan model Gaudya Vaisnava meliputi fungsi sosial dan fungsi religius. Fungsi sosial adalah upaya pasraman mendorong individu anggota dan partisipannya untuk melaksanakan tugas-tugas kehidupan dirinya sendiri, keluarganya, kelompok sosialnya, dan masyarakat lingkungan sekitarnya untuk berinteraksi dengan lingkungan sosialnya. Sedangkan fungsi religius dimaksudkan sebagai usaha mewujudkan fungsi kerohanian.

Makna pembinaan keagamaan model Gaudya Vaisnava juga meliputi makna sosial dan makna regius. Makna yang bersifat sosial, bermakna peningkatan kualitas interaksi dan komunikasi sosial antara anggota yang satu dengan anggota yang lain. penegakan dan perjuangan harkat dan martabat kemanusiaan sesuai Ajaran Hare Krishna. Sedangkan makna yang bersifat religius, mengandung prinsipprinsip untuk merohanikan seluruh kehidupan di dunia ini melalui aktivitas japa, kirtana, dan ritual.

Kegiatan pembinaan keagamaan model Gaudya Vaisnava, telah terlaksana bagi internal organisasinya. Upaya mempersuasi orang lain di luar organisasi, agar dilakukan secara hatihati, jangan sampai merusak hubungan intern sesama umat Hindu maupun hubungan ekstern dengan umat beragama lainnya.

Pembinaan keagamaan model Gaudya Vaisnava sedang diupayakan untuk meningkatkan kualitas kerohanian para anggotanya. Namun demikian belum tentu cocok sepenuhnya bagi pembinaan kelompok-kelompok keagamaan Hindu tradisional Bali. Bagi pembina Hindu tradisional Bali mungkin dapat bercermin pada keberhasilan kelompok ini, terutama dalam upaya menarik dukungan dari kelompok lain dan mengarahkan menjadi pengikutnya. Hal ini dapat dijadikan semacam inspirasi untuk menyusun model pembinaan yang lebih sesuai dengan sistuasi sosial budaya masyarakat Bali.

Hasil penelitian ini dapat digunakan sebagai bahan kajian pustaka bagi rencana penelitian lain yang sejenis dengan topik yang berbeda.

\section{DAFTAR PUSTAKA}

Depdikbud, 1991, Kamus Besar Bahasa Indonesia, Jakarta: Balai Pustaka.

Hamad, Ibnu, 2004, Konstruksi Realitas Politik dalam Media Massa: Sebuah Studi Critical Discourse Analisis Terhadap Berita-Berita Politik. Jakarta: Dranit. 
Kesidamana dasa, 2005. Sri Hari Bhakti Vilasa and Panca-Samskara. Brhat Medganga Press. Thomson Press New Delhi.

Piliang, Amir, 2003. Hipersemiotika, Tafsir Cultur Studied Atas Matinya Makna. Bandung: Asutra. 128 UpacaraMediksa Pasek Sanak Sapta Kesi

Poloma, Margaret M, 1994, Sosiologi Kontemporer, Yogyakarta: Yayasan Solidaritas Gajah Mada, Jakarta : PT Raja Grafindo Persada.

Pudja, Gede, 1985, Pengantar Agama Hindu, Jilid I Untuk Perguruan Tinggi, Jakarta : Mayasari.

Puja, I Gede dan Sudana, Tjokorda Rai. 2002. Manawadharmasastra. Jakarta: CV Pelita Jaya.

Prem P.Bhalla, 2010 Tata Cara, Ritual dan Tradisi Hindu, Paramita Surabaya.(alih Bahasa: Diah Sri Pandewi)

Ritzer, George dan Douglas J. Goodman, 2004. Teori Sosiologi Modern, Edisi Keenam, Jakarta : Kencana.

Titib, I Made. 2003. Teologi dan Simbolsimbol dalam Agama Hindu. Surabaya: PT. Paramaitha. 